\title{
Non-Performing Loan Determinants during COVID-19 Pandemic (Case Study at Bank XYZ)
}

\author{
Didi Suradi $^{1}$, Hermanto Siregar ${ }^{2}$, Bagus Sartono ${ }^{3}$ \\ ${ }^{1}$ School of Business, IPB University, Jl. Raya Padjajaran Bogor, Indonesia \\ ${ }^{2}$ Department of Economics, Faculty of Economics and Management, IPB University, Jl. Kamper, Wing 4, \\ Level 5, IPB Darmaga Bogor 16680 \\ ${ }^{3}$ Department of Statistics, Faculty of Mathematics and Natural Science, IPB University
}

Corresponding Author: Didi Suradi

\begin{abstract}
Non-Performing Loans (NPL) is a financial ratio that shows the credit risk faced as a result of granting credit and investment funds on different portfolios. This study aimed to analyze the determinants of Non-Performing Loans (NPL) before and during the Covid 19 pandemic at Bank XYZ. NPL can be caused by internal or external factors from Bank XYZ. The analytical method used is the Mixed method which combines quantitative and qualitative analysis. Data analysis used multiple linear regression method using time series data for the 1st quarter of 2013- 4th quarter of 2020. The analysis method used multiple linear regression to see the influence of internal factors are total credit, Return on Equity, Loan to Deposit Ratio, Net Interest Margin, total assets, BOPO, condition dummy before after transformation and external factors are Benchmark Interest Rate, exchange rate (exchange rate), Inflation, Industry Production Index, dummy conditions before and during the Covid 19 pandemic on Bank XYZ's NPL. The estimated regressions are the overall NPL, the Small Medium Enterprise (SME) Business Segment NPL, the Small Medium Enterprise (SME) Business Segment for the wholesales business sector, and the Small Medium Enterprise (SME) Business Segment NPL for the Retailer business sector. Data processing using E-views software version 9.0. The result of this research are factors that affect the overall NPL: Dummy Transformation, Net Interest Margin, and total assets, for the NPL for the Small and Medium Enterprises (SME) segment: total assets, dummy transformation
\end{abstract}

and Net Interest Margin (NIM), NPL for the Small and Medium Enterprises (SME) business sector Wholesales: BOPO NIM, Lending growth, total assets, ROE and Dummy Transformation, for the NPL segment of Small and Medium Enterprises (SMEs) Retailer business sector: Net Interest Margin (NIM) and total assets. The impact of the COVID-19 pandemic on NPLs was most felt by the NPL all, SME business segment credit and the wholesales business sector.

Keywords: covid-19 pandemic, NPL, NPL SME, retailer, wholesales

\section{INTRODUCTION}

Bank is a financial intermediary institution that is tasked with collecting and distributing funds in the community to improve people's living standards (Law Number 10 of 1998). Banks are financial institutions that have an important role in determining the country's economy because their existence can affect microeconomic and macroeconomic movements. The main function of a bank is to collect and distribute funds as well as other bank service providers. The main activities of Commercial Banks are collecting and distributing funds, while providing other bank services is only a supporting activity.

Commercial Bank profits are obtained from the difference between interest income and costs incurred by the bank. Interest income is derived from the 
difference between interest charged to debtors and interest paid to depositors. The Bank also earns non-Interest income derived from Fee based Income which is a fee obtained by the bank for banking services charged to customers.

Banks must be able to mitigate credit risk so that the loans disbursed will actually become a burden because for every NonPerforming Loan, the bank must provide reserves which will be recorded as costs and can reduce profits. The risk of lending will be greater if the amount disbursed is greater, therefore banks are required to be more observant in conducting credit analysis in order to avoid getting debtors who have the potential to become Non-Performing Loans. Banks that can survive and earn profits are banks that can achieve credit growth and keep debtor's payment performance smooth.

XYZ Bank credit experienced negative growth in 2015 and 2016, due to a decline in the corporate and commercial segments. Positive growth again occurred in 2017 to 2019 which was supported by good growth in the Small and Medium Enterprises (SME) and Enterprise Banking segments. In 2020 there was another decline due to the economic slowdown caused by the COVID-19 pandemic.

Credit data on a quarterly basis from 2015 to the second quarter of 2020 shows that the highest credit of Bank XYZ occurred in the first semester of 2019, which was Rp. 148 Trillion. In general, the movement of $\mathrm{XYZ}$ Bank credit is in the range of Rp. 120 trillion up to Rp. 148 Trillion. Based on Bank XYZ publication reports, the highest negative growth occurred in the 4th quarter of 2015, while the highest positive growth occurred in the 2nd quarter of 2019.

Non-Performing Loans at Bank XYZ for the period 2015 to December 2020 can be seen in table 1. In general, NonPerforming Loans at Bank XYZ are still around 3 percent, where this figure is still below Bank Indonesia's tolerance limit of 5 percent. Bank XYZ must be aware of the NPL position in 2020 due to the economic slowdown due to the Covid 19 pandemic. Bank XYZ needs to be careful in monitoring debtors who are included in special mentions because there is a possibility of worsening collectability and becoming Non-Performing Loans.

Table 1. Total NPL and percentage of NPL Bank XYZ 2015-2020

\begin{tabular}{|l|l|l|l|l|l|l|}
\hline NPL & $\mathbf{2 0 1 5}$ & $\mathbf{2 0 1 6}$ & $\mathbf{2 0 1 7}$ & $\mathbf{2 0 1 8}$ & $\mathbf{2 0 1 9}$ & $\mathbf{2 0 2 0}$ \\
\hline (Rp. Billion) & 4,295 & 4,247 & 3,643 & 3,955 & 4,541 & 4,040 \\
\hline NPL (\%) & $3.32 \%$ & $3.47 \%$ & $2.92 \%$ & $2.94 \%$ & $3.21 \%$ & $2.98 \%$ \\
\hline
\end{tabular}

Based on the Non-Performing Loan data on a quarterly basis, there was an unfavorable development at the beginning of the Covid 19 pandemic, the highest NPL occurred in the second semester of 2020 at 4.24 percent. Bank XYZ's NPL tends to move up due to slowing credit growth and the onset of the covid 19 pandemic. In the 3rd and 4th quarters of 2020 Bank XYZ has started to control the NPL, and at the close of the 4th quarter it was at 2.98 percent. The Non-Performing Loan segment of Small and Medium Enterprises (SMEs) has deteriorated in the last four years, the position as of December 31, 2017 was initially at 2.92 percent, increasing significantly to 6.69 percent in December
2020. The Small and Medium Enterprises (SME) credit segment) being the most affected by the COVID-19 pandemic because they are most vulnerable to external factors.

An increase in Non-Performing Loans can result in increased reserve costs and reduce bank profitability, the challenges ahead for credit are also increasingly challenging due to macro conditions, increasingly fierce competition between banks and the impact of the Covid 19 pandemic. Bank XYZ needs to identify the factors that influence Non-Performing Loans.

The results of Rajha's research (2016) which analyzed the determinants of 
NPL from macroeconomic factors and bank-specific factors (internal) for banking in Jordan. Bank specific factors (internal): NPL of the previous year, Risk appetite as measured by Loans to total assets ratio, bank size (measured by total assets). Macroeconomic factors: economic growth, average bank interest rates, inflation, dummy factors before and after the global crisis. The result is bank-specific factors (internal), namely the previous year's NPL has a significant and positive effect, risk appetite has a significant and positive effect, bank size has a positive but not significant effect on NPL. Macroeconomic factors of economic growth have a negative and significant effect, inflation has a negative and significant effect, the economic crisis dummy has a positive and significant effect on NPL, the most influential is total assets and is positively related. Macroeconomic factors GDP and inflation have a significant negative relationship with the NPL.

Rathria et al. (2018) analyzed bankspecific factors (internal) that affect NPL in developing countries (case study in Indonesia) processing data using a regression panel with NPL (\%) as the dependent variable, credit growth (\%), Profitability measured by Return on Average Asset (ROAA), Operating Efficiency is measured by Non Interest expense ratio, Capital is measured by Equity to Asset Ratio, Income Diversification is measured by Non Interest Income ratio as an independent variable. The results showed that profitability and credit growth had a negative effect on NPL, while operating efficiency, capital and income diversification had no significant effect on NPL.

Ekanayake et al. (2015) analyzed the determinants of NPL in Commercial Banks in Sri Lanka both macroeconomic factors and from internal banks. Data processing using fixed effect panel data regression function. The determinants of NPL due to macroeconomics: GDP growth, inflation, unemployment, and basic interest rates. Bank-specific factors (internal): efficiency, risk profile, credit growth, bank size, previous year's NPL. As a result, the variables of economic growth and inflation have a negative and significant effect on NPL. While the average base interest rate has a positive and significant effect on NPL. The most influential bank-specific factor (internal) is total assets and is positively related. The bank's risk profile, as measured by the loan to asset ratio and loan loss provision ratio, shows a positive relationship to the NPL. Credit growth is negatively related to NPL. Bank efficiency factor has a negative effect on NPL.

The external factor being faced by banks is the Covid 19 pandemic which has an impact on the continuity of the debtor's business. The Financial Services Authority (OJK) as the OJK regulator issued POJK Number 11/POJK.03/2020 concerning National Economic Stimulus as a Countercyclical Policy. Based on data as of November 30, 2020, the number of SME debtors who carried out credit restructuring was 5.8 million debtors with a total credit value of Rp. 383 trillion. POJK Number 11/POJK.03/2020 is the basis for Bank $\mathrm{XYZ}$ to make regulations internally to provide credit restructuring for debtors affected by the COVID-19 pandemic.

Based on the description above, the researcher is interested in researching related internal and external factors that affect Bank XYZ's Non-Performing Loan. The formulation of the problem in this study include:

1. How was the condition of NonPerforming Loans at Bank XYZ as a whole and specifically in the Small and Medium Enterprises (SME) segment during the Covid 19 pandemic?

2. What are the effects of external and internal factors on Non-Performing Loans at Bank XYZ as a whole and specifically in the Small and Medium Enterprises segment during the Covid 19 pandemic? 


\section{LITERATURE REVIEW Credit}

Credit in a simple economic sense is a delay in payment. This means that goods or money received now will be returned in the future. The term credit comes from the Greek "Credere" which means trust and trust is contained in the credit of the credit giver and recipient. According to Jopie Jusuf (2014), credit is the ability to carry out a purchase or make a loan with a promise that payment will be made within the agreed period.

\section{Credit Purpose and Function}

According to Triwahyuniati (2008) there are 2 interrelated functions with credit, namely profitability and safety. Profitability is the purpose of obtaining results from credit in the form of profits from interest that must be paid by the debtor. Safety is the security of the achievements or facilities provided must be truly guaranteed so that the profitability goals can be achieved without significant obstacles.

\section{Bank Risk}

According to PBI NO.
$11 / 25 / \mathrm{PBI} / 2009$ concerning the Implementation of Risk Management for Commercial Banks, Banks are required to implement risk management effectively, at least covering:

- Active supervision of the Board of Commissioners and the Board of Directors

- Adequacy of policy procedures, and determination of risk management limits

- Adequacy of risk identification, measurement, monitoring and control processes, as well as Risk Management Information System

- Comprehensive internal control system.

\section{Small and Medium Enterprises (SME)}

The Central Statistics Agency (BPS) provides a definition of Micro, Small and Medium Enterprises (MSMEs) based on the number of workers. Small businesses are businesses that have a workforce of 5 to 19 people, while medium-sized businesses are businesses that have a workforce of 20 to 99 people.

\section{Definition of Non-Performing Loan}

Credit quality is determined into several categories, namely: current, special mention, substandard, doubtful and loss. According to PBI No. 14/15/PBI/2012, Banks are required to calculate the Allowance for Asset Losses (PPA) for productive assets and non-earning assets. Loans that have collectibility of 3, 4 and 5 are included in the Non-performing Loan category. NPL is one of the benchmarks for the health of a bank. Non-Performing Loan is the ratio between non-performing loans and total loans granted by the Bank.

\section{Factors influencing NPL}

According to Siamat (2015), from the Bank's perspective, NPL occurs due to various factors including:

- Internal Factors

- External Factors

- Loan Review

\section{METHOD}

The research was conducted at Bank XYZ. Bank XYZ was chosen purposively with the consideration that Bank XYZ's credit portfolio is included in the top ten banks in Indonesia and the increase in NPL in the SME segment due to the impact of the COVID-19 pandemic resulted in Bank XYZ's profits falling. The time of the study was carried out in April to July 2021.

The study uses secondary data, sourced from access to internal data of Bank $\mathrm{XYZ}$, external data and third parties. The data is obtained from the Quarterly and Annual Financial Reports of Bank XYZ, reports from the Research Institute of Bank Indonesia and the Financial Services Authority (OJK) as well as various other external sources. The data used is the period from January 2013 to December 31, 2020. The data obtained is time series data so that for quantitative analysis using linear regression with dummy variables. The 
regression model for the analysis of external and internal influences on NPL is as follows:

$\mathbf{Y}=\mathbf{b}_{0}+\mathbf{b}_{1} *$ BOPO $+\mathbf{b}_{2}{ }^{*}$ NIM $+\mathbf{b}_{3}{ }^{*}$ Growth $+\mathbf{b}_{4}{ }^{*}$ Asset + $\mathbf{b}_{5} *$ ROE $+\mathbf{b}_{6} *$ LDR $+\mathbf{b}_{7} *$ Transformation Dummy + $\mathbf{b}_{8} *$ Inflation $+\mathbf{b}_{9} * \mathbf{R E P O}+\mathbf{b}_{10} *$ Exchange Rate $+\mathbf{b}_{11} *$ IPX + $\mathrm{b}_{12}{ }^{*}$ Pandemic Dummy $+€$
The independent variable data is data from Bank XYZ. In detail for the operational definition of variables in the study can be seen in Table 2 .

Table 2. Operational definitions of research variables

\begin{tabular}{|c|c|c|c|}
\hline No & Description & Scale & Data Source \\
\hline 1 & Non- Performing Loan & $\%$ & $\mathrm{NPL}=\frac{\text { Nonperforming loans }}{\text { Total loans }} \times 100 \%$ \\
\hline 2 & Inflation & $\%$ & $\begin{array}{l}\text { The ratio of the difference between the current year's CPI compared to the previous } \\
\text { year's CPI }\end{array}$ \\
\hline 3 & Benchmark Interest Rate & $\%$ & BI 7 days repo rate determined by Bank Indonesia \\
\hline 4 & Exchange Rate & $\%$ & $\begin{array}{l}\text { Changes in the exchange rate used is the exchange rate of the Rupiah against the US } \\
\text { Dollar which is measured at the middle rate of the previous period }\end{array}$ \\
\hline 5 & Industry Production Index & $\%$ & IPX growth at any given time compared to the previous time period \\
\hline 6 & Lending Growth & $\%$ & Current year's outstanding growth compared to the previous year's outstanding \\
\hline 7 & Return on Equity & $\%$ & ROE $=\frac{\text { Net Income }}{\text { Equity }} \times 100 \%$ \\
\hline 8 & Loan to Deposit Ratio & $\%$ & LDR $=\frac{\text { Total Loans } \times 100 \%}{\text { Total Deposits }}$ \\
\hline 9 & Net Interest Margin & $\%$ & $\mathrm{NIM}=\frac{\text { (Investment Income- Interest Expenses })}{\text { Average Earning Assets }} \times 100 \%$ \\
\hline 10 & Total Assets & $\%$ & Asset growth in year t compared to year t-1 \\
\hline 11 & $\begin{array}{l}\text { BOPO (Operational Cost of } \\
\text { Operating Income) }\end{array}$ & $\%$ & $\mathrm{BOPO}=\underline{\text { Operating expenses }} \times 100 \%$ \\
\hline 12 & Transformation Dummy & & $\begin{array}{l}0 \text { for before transformation } \\
1 \text { for after transformation }\end{array}$ \\
\hline 13 & Pandemic Dummy & & $\begin{array}{l}0 \text { for before Covid } 19 \text { pandemic } \\
1 \text { for the time of Covid } 19 \text { pandemic }\end{array}$ \\
\hline
\end{tabular}

There are four regressions consisting of the overall NPL, the NPL for the SME segment, the NPL for the SME segment for the wholesales business, and the NPL for the SME segment for the retailer business sector of Bank XYZ. The wholesales and retailer business sectors are the two business segments that provide the largest contribution to the SME loan portfolio.

Based on several theoretical foundations and previous research as well as the variables described in this research, a research hypothesis can be formulated: The relationship between the independent variables and NPL are: BOPO variable is negatively related, NIM is positively related, Lending Growth is negatively related, total assets is positively related, ROE positively related, Loan to Deposit Ratio positively related, Inflation positively related, Benchmark interest rate positively related, Exchange rate positively related, IPX negatively related. NPL during the pandemic is higher than before the Covid 19 pandemic, and NPL after the transformation is higher than before the transformation.

\section{RESULT AND DISCUSSION Descriptive Analysis}

The results of descriptive analysis for the dependent variable data which is data from the 1st quarter of 2013 to the 4th quarter of 2020 are as follows: a) Bank XYZ's overall NPL shows an average of $3.13 \%$ with a minimum value of $2.03 \%$ and a maximum of $4.24 \%$, b) Segment NPL Small Medium Enterprise (SME) average of $3.57 \%$ with a minimum value of $1.28 \%$ a maximum of $7.91 \%$, c) The NPL of the Small Medium Enterprise (SME) segment of the wholesales business sector is an average of $3.78 \%$ with a minimum value of $1.22 \%$ maximum $8.54 \%$ d) The NPL of the Small Medium Enterprise (SME) segment of the retailer business sector is an average of $4.73 \%$ with a minimum value of $1.74 \%$ and a maximum of 8.21 .\%. NPL The SME segment, both the wholesales and retailer business segments and the SME sector, has 
a higher average NPL than Bank XYZ's overall NPL.

The results of descriptive analysis for independent variable data which are data from quarter 1 of 2013 to quarter 4 of 2020 are as follows: a) BOPO shows an average of $77.99 \%$ with a minimum value of $69.30 \%$ a maximum of $89.59 \%$ b) Net Interest Margin shows an average average 6.79\% with a minimum value of $5.02 \%$ maximum 8.76\% c) Lending Growth overall shows an average of $-0.43 \%$ with a minimum value of $-3.8 \%$ maximum $6.93 \%$ d) Lending Growth SME shows an average of $0.88 \%$ with a minimum value of $-6.05 \%$ maximum $11.41 \%$ e) Lending Growth SME Wholesales shows an average of $0.96 \%$ with a minimum value of $-8.91 \%$ a maximum of $10.57 \%$ f) Lending Growth in SME Retailers shows an average of $0.93 \%$ with a minimum value of $-9.79 \%$ a maximum of $8.10 \%$ g) Total assets shows an average $0.75 \%$ with a minimum value of $-4.86 \%$ maximum $8.66 \%$ h) Return on Equity shows an average of $10.72 \%$ with a minimum value of $2.60 \%$ maximum $28.23 \%$ i) Loan to Deposit Ratio shows an average of 93. $87 \%$ with a minimum value of $83.96 \%$ a maximum of $105.39 \%$ j) Inflation shows an average of $4.31 \%$ with a minimum value of $1.42 \%$ a maximum of $8.36 \% \mathrm{k}$ ) the exchange rate shows an average of $0.29 \%$ with a minimum value of $-0.14 \%$ a maximum of $15.20 \%$ l) Industry Production Index shows an average of $3.88 \%$ with a minimum value of $-7.12 \%$ a maximum of $9.88 \% \mathrm{~m}$ ) Benchmark interest rate shows an average of $5.83 \%$ with a minimum value of $3.75 \%$ and a maximum of $7.75 \%$.

\section{Classic Assumption Test}

Before analyzing the results of the regression results, the classical assumption test is carried out first, the results are as follows:

Table 3. Classical Assumption Test Results

\begin{tabular}{|l|l|l|l|l|}
\hline Test & NPL All & NPL SME & NPL SME Wholesales & NPL SME Retailer \\
\hline $\begin{array}{l}\text { Normality } \\
\text { (Jarque -Barbera) }\end{array}$ & $\begin{array}{l}\text { Normal } \\
\text { P value }>0.05\end{array}$ & $\begin{array}{l}\text { Normal } \\
\text { P value } 0,3450>0.05\end{array}$ & $\begin{array}{l}\text { Normal } \\
\text { P value } 0,733>0.05\end{array}$ & $\begin{array}{l}\text { Normal } \\
\text { P value }>0.05\end{array}$ \\
\hline Autocorrelation (Brusch- Godfrey) & P Value $0,0937>0,05$ & P Value $0,2931>0,05$ & P Value $0,3086>0,05$ & P Value $0,056>0,05$ \\
\hline Heteroscedasticity (Glejser Test) & P Value $0,1467>0,05$ & P Value $0,3618>0,05$ & P Value $0,3618>0,05$ & P Value $0,0761>0,05$ \\
\hline Linearity (Ramsey reset test) & P Value $0,1673>0,05$ & P Value $0,0632>0,05$ & P Value $0,0522>0,05$ & P Value $0,7580>0$ \\
\hline Multicollinearity (VIF) & VIF $<10$ & VIF $<10$ & VIF $<10$ & VIF $<10$ \\
\hline
\end{tabular}

Based on table 3, it shows that the estimated model has met the classical assumptions because it has passed the normality test, autocorrelation test, heteroscedasticity test, linearity test and multicollinearity test.

\section{Influence of Internal and External Factors on NPL}

\section{- T test results statistic}

The regression results for each model can be seen in table 4 below:

Table 4. Regression Results for each model

\begin{tabular}{|c|c|c|c|c|c|c|c|c|}
\hline \multirow[t]{2}{*}{ Variable } & \multicolumn{2}{|l|}{ Total NPL } & \multicolumn{2}{|l|}{ NPL SME } & \multicolumn{2}{|c|}{ NPL SME Wholesales } & \multicolumn{2}{|c|}{ NPL SME Retailer } \\
\hline & $\begin{array}{l}\text { Coefficient } \\
\text { Value }\end{array}$ & Probability & $\begin{array}{l}\text { Coefficient } \\
\text { Value }\end{array}$ & Probability & $\begin{array}{l}\text { Coefficient } \\
\text { Value }\end{array}$ & Probability & $\begin{array}{l}\mathbf{N} \\
\text { Coefficient } \\
\text { Value }\end{array}$ & Probability \\
\hline BOPO & -0.0108 & 0.4916 & 0.0337 & 0.2296 & 0.0466 & $0.0403^{* *}$ & 0.0043 & 0.8816 \\
\hline NIM & 0.1651 & $0.0933 *$ & -0.5479 & $0.0095 * *$ & -0.4680 & $0.0137 * *$ & -0.9684 & $0.0003 * *$ \\
\hline $\begin{array}{l}\text { Lending } \\
\text { Growth }\end{array}$ & -0.0078 & 0.7912 & -0.0391 & 0.3662 & -0.0509 & $0.0827 *$ & 0.0050 & 0.9001 \\
\hline Total Assets & -0.0458 & $0.0806^{*}$ & -0.1105 & $0.0050 * *$ & -0.0546 & $0.0846 *$ & -0.0923 & $0.0410^{* *}$ \\
\hline $\mathrm{ROE}$ & -0.0047 & 0.8053 & 0.0323 & 0.3075 & 0.0481 & $0.0949 *$ & 0.0013 & 0.9718 \\
\hline LDR & 0.0177 & 0.3369 & 0.0080 & 0.7665 & 0.0250 & 0.2923 & -0.0434 & 0.1736 \\
\hline $\begin{array}{l}\text { Transformation } \\
\text { Dummy }\end{array}$ & 0.0091 & $0.001 * *$ & 0.0119 & $0.0073^{* *}$ & 0.0125 & $0.0020^{* *}$ & 0.0050 & 0.2937 \\
\hline Inflation & -0.0664 & 0.2600 & -0.0310 & 0.7412 & -0.0640 & 0.4484 & 0.0551 & 0.6189 \\
\hline Exchange rate & -0.0014 & 0.9133 & 0.0130 & 0.5349 & -0.0000 & 0.9776 & 0.0063 & 0.8082 \\
\hline IPX & -0.0187 & 0.3029 & -0.0200 & 0.5105 & -0.0374 & 0.1521 & -0.0329 & 0.3484 \\
\hline $\begin{array}{l}\text { Benchmark } \\
\text { Interest Rate }\end{array}$ & 0.0370 & 0.6999 & -0.0410 & 0.7940 & -0.2720 & $0.0560 *$ & -0.1837 & 0.3191 \\
\hline
\end{tabular}




\begin{tabular}{|l|l|l|l|l|l|l|l|l|}
\hline \multicolumn{7}{|c|}{ Table 4 Continued... } \\
\hline $\begin{array}{l}\text { Pandemic } \\
\text { Dummy }\end{array}$ & 0.0049 & $0.0944^{*}$ & 0.0197 & $0.0004^{* *}$ & 0.0275 & $0.0000^{* *}$ & 0.0089 & 0.1115 \\
\hline R squared & 0.8257 & 0.9530 & 0.9762 & 0.9361 \\
\hline Prob (F stat) & 0.000 & 0.000 & 0.000 & 0.000 \\
\hline
\end{tabular}

The effect of the BOPO variable on Non-Performing Loans (NPL) has a negative effect on the overall NPL, on the contrary, the NPL of SME, NPL of SME Wholesales and SME Retailers has a positive effect. The BOPO variable shows how efficient a bank is. The BOPO variable has a significant effect on the NPL of SME Wholesales. The higher the BOPO of a bank, the more inefficient the bank is because operational costs are higher than operating income, so the bank has the potential to be in a problematic condition. The results of this study are in line with Barus et al. (2016).

The NIM variable has a significant effect on the overall NPL, NPL SME, NPL SME Wholesales and SME Retailers. The results for the effect of the NIM variable on the overall NPL are in line with the conclusions of Barus et al. (2016). A high interest income margin will make banks provide high interest to debtors so that the possibility of bad loans will increase. Meanwhile, the effect of NIM on NPL SME, NPL SME Wholesales and SME Retailers which have a negative relationship is in line with Santoso (2019) research. In the SME segment, the interest rates charged to debtors are generally higher than in other segments.

The lending growth variable only has a significant effect on SME Wholesales. The results of the research on the effect of lending growth variables for overall NPL, NPL SME, and NPL SME Wholesales are in line with research by Rathria et al. (2018) and Ekanayake et al. (2015) which have a negative relationship with NPL. If credit grows, the bank's opportunity to reduce NPL is greater, provided that it must grow with a quality portfolio.

The total asset variable has a negative and significant effect on the overall NPL, NPL of SME, and NPL of SME
Wholesales and SME Retailers. It can be explained that with the addition of assets, banks can get the flexibility to provide credit to quality debtors so that the potential for NPLs can be suppressed. The results of this study are in line with the results of research by Rathria et al. (2018) and Ekanayeke (2015).

The Return on Equity variable has a positive effect on the NPL of SME, and NPL of SME Wholesales, NPL of SME Retailers. Meanwhile, the overall NPL has a negative effect. The Return on Equity variable only has a significant effect on SME Wholesales. This can be explained that with an increase in ROE, management tends to charge higher interest to debtors, and in the end increases the opportunity for NPLs to occur. The results for the ROE variable on the NPL of SME Wholesales are the results of Santoso's research (2019).

There is no LDR variable that significantly affects NPL. The transformation dummy variable shows that the NPL after the transformation has increased compared to before the transformation. The transformation dummy variable significantly affects the overall NPL, NPL SME and NPL SME Wholesales. This can be explained by the unification of various divisions in the branch forum, making credit marketers who usually focus on the acquisition of debtors become disoriented because they have to acquire other products. The results of this study are supported by the research results of Setianingsih et al. (2016).

There is no inflation variable that has a significant effect on NPL. The results for retailers' NPL are in accordance with the results of Kamaludin's research (2015) while the results for SME NPL, SME Wholesales NPL are in accordance with Rajha (2016), Ekayanake et al. (2016), Saba et al. (2015). If inflation occurs, the price of 
goods tends to increase so that purchasing power decreases, the impact on business actors is that it will result in a decrease in turnover and in the end there will be a potential for failure to pay to the bank. The exchange rate and IPX variables have no significant effect on the overall NPL, while for the NPL of SME, NPL of SME Wholesales and NPL of retailers.

The benchmark interest rate variable, in this case, is the reference interest rate which refers to the BI 7 days repo rate, which is only significant to the NPL of SME wholesales and has a negative effect. If there is an increase in the benchmark interest rate, the bank will usually make adjustments to the loan interest. An increase in credit interest will result in a potential default from the debtor. The results of this study are supported by the results of research by Setianingsih et al. (2016) and Raksong (2016).

The pandemic dummy variable shows that the NPL during the pandemic has increased compared to before the covid 19 pandemic. The pandemic dummy variable significantly affects the overall NPL, NPL SME and NPL SME Wholesales. The explanation is that due to the pandemic, many Bank XYZ debtors have been affected, causing payment obligations to be disrupted. These results are in line with the conclusions of Rajha (2016), the dummy variable before and after the crisis is positively related to NPL. The impact of the economic crisis made NPLs increase when compared to conditions before the crisis. The SME Retailer's NPL has no significant effect but is close to the level of $=10 \%$, this can be explained because the SME retailer's NPL trend has indeed worsened before the pandemic, many debtors are experiencing difficulties because they cannot adapt to the development of online retail sales.

\section{- F Test Statistics and Coefficient of Determination}

The results of the $\mathrm{F}$ test show that the P-value of 0.000 is smaller than the 0.05 significance level, so it can be concluded that the independent variables simultaneously affect the overall NPL, SME NPL, SME Wholesales business sector, SME retailer business sector at Bank XYZ. Based on the coefficient of determination (R2/R-Square) the overall NPL regression model is $82.57 \%$, the SME NPL regression model is $95.3 \%$, the SME NPL regression for the Wholesales business segment is 97.63\% and the SME NPL for the retailer business segment is $93.61 \%$.

\section{CONCLUSION}

1. The overall Non-Performing Loan (NPL) condition of Bank XYZ has begun to improve in the 3rd quarter of 2020, while the Non-Performing Loan (NPL) of Bank XYZ's Small and Medium Enterprises segment is still deteriorating.

2. Simultaneously, the determinants of internal factors and external factors significantly influence the NonPerforming Loan (NPL).

3. The impact of the Covid 19 pandemic on NPL has the most significant effect on overall NPL, NPL for the SME segment and NPL for the wholesale business sector.

\section{Acknowledgement: None}

\section{Conflict of Interest: None}

\section{Source of Funding: None}

\section{REFERENCES}

1. Barus AC, Erick. 2016. Analysis of factors affecting Non-Performing Loan at Commercial Banks in Indonesia. Journal of Wira Economics Mikroskil.6 (2):113-122.

2. Brikena L, Etieva B, Ejona D. 2019. Key Macroeconomic Drivers on Reducing NonPerforming Loans in Albania. Academic Journal of Interdiscplinary Studies. 8 (2):8895.

3. Effendi N, Setiawan M. 2013. Ekonometrika, Pendekatan dan Teori. Jakarta (ID). Salemba Empat.

4. Ekanayake EMNN, Azeez AA. 2015. Determinants of Non-Performing Loans in 
Licensed Commercial Banks: Evidence from Srilanka. Asian Economic and Financial Review. 5 (6): 2305-2147.

5. Franklin Amuakwa M, Angela Boakye A. 2015. Determinans of Non-Performing Loans in Ghana Banking Industry. International Journal Economics and Econometrics. 5 (1):35-54.

6. Ghozali, Imam. 2006. Application of Multivariate Analysis with SPSS Program (4th Edition). Semarang (ID). Diponegoro University Publishing Agency.

7. Ginting AM. 2017. The Influence of Macroeconomic Factor to Non Performing Loan (NPL) Bank. Journal of Economics and Public Policy 7(2):159-170.

8. Hariyanto K. 2015. Determinants of relationship quality and closeness of relationships in providing banking credit services to micro-enterprises and their effect on customer satisfaction and loyalty. Journal of Business \& Banking. 4(2):231-244.

9. Ibish M, Fisnik M, valdrin M, Jonathan V S, Simon G. 2018. Determinants of the level of Non-Performing Loans in commercial banks of Transition Countries. European Research Studies Journal. 21:3-13.

10. Iswi, Haryani. 2010. Restructuring \& Elimination of Bad Loans. Jakarta (ID). PT. Gramedia, Jakarta.

11. Jopie Yusuf. 2014. Basic Guide for Account Officers. Jakarta (ID). UPP STIM YKPM.

12. Joseph MT. Edson G, Manuere F, Clifford M, Michael K. 2012. Non-Performing Loans in Commercial Banks: A Case of CBZ Bank Limited in Zimbabwe. Interdisciplinary Journal of Contemporary Research in Business. 4(7):467-488.

13. Kamaludin, Darmansyah, Berto U. 2015. Determinants of Non-Performing Loans (NPL) in the Banking Industry (Empirical Evidence of Companies Go Public on the Indonesia Stock Exchange). Journal of Management Applications. 13 (4):547-556.

14. Cashmere. 2014. Banks and Other Financial Institutions, Revised Ed. Jakarta (ID): Raja Grafindo Perkasa (Rajawali Press).

15. Kuncoro, M. 2004. Quantitative Methods: Theory and Applications to Business and Economics. 2nd Edition. Yogyakarta (ID). AMP YKPN.

16. Louzis DP, Vouldis AT, Metaxas VL. 2011. Macroeconomic and bank specific determinants of non-performing loans in Greece: A comparative study of mortgage, business and consumer loan portfolios. Journal of Banking and Finance. 36: 10121027.

17. Musthikaningtyas NR. 2011. Analysis of factors influencing Non-Performing Loans (NPLs) for Public Housing Loans. (Thesis). Bogor (ID). IPB University.

18. Financial Services Authority. 2014. POJK No. 29/POJK.05/2014. Jakarta (ID). Financial Fervices Authority.

19. Poetry ZD, Sanrego YD. 2014. The effect of macro and micro variables on the NPL of conventional banking and NPF of Islamic banking. Tazkia Islamic Finance and Business Review. 6(2):79-104.

20. Putong I. 2010. Introduction to Micro and Macroeconomics. Jakarta (ID). Media Discourse Partners.

21. Rajha, KS. 2016. Determinants of NonPerforming Loans: Evidence from the Jordanian Banking Sectors. Journal of Finance and Bank Management. 4 (1) 125136.

22. Raksong S, Yu Byungho, Raksong Y. 2019. Analysis of The Determinants of NonPerforming Loans in Thailand: Empirical Study of the SMEs Non-Performing Loans. Journal of Applied Economic Sciences. 3:65

23. Rathria AR, Yohanes B K, Kevin A, Robertus S. 2018. Bank Specific Factors Affecting Non-Performing Loans in Developing Countries: Case study of Indonesia. Journal of Asian Finance, Economics and Business. 5(2): 35-42.

24. Saba I, Kouser R, Azeem M. 2012. Determinants of Non-Performing Loans case of US Banking Sector. The Romanian Economic Journal 44:125-136.

25. Serhat Yuksel .2017. Determinants of Credit Risk in Developing Countries After Economic Crisis: A Case of Turish Banking Sector. Turkey (TR): Springer International Publishing AG.

26. Setiawan, M. 2006. Multivariate Regression and Classical Regression Assumption Testing. Bandung (ID). Padjadjaran University.

27. Setiyaningsih S, Juanda B, Fariyanti A. 2015. Factors influencing the ratio of NonPerforming Loans (NPL). Journal of Business and Management Applications 1(1):23-33.

28. Siamat D. 2005. Management of Financial Institutions. Jakarta (ID): Economics University of Indonesia. 
29. Indonesian Banking Statistics. 2019. Jakarta (ID). Financial Services Authority.

30. Suardi I. 2016. Analysis of the factors that influence the Non-Performing Loan (NPL) of micro credit and its impact on lending to the micro sector at PT Bank XYZ regional office X. (Thesis). Bogor (ID). IPB University.

31. Sutoyo S. 2017. Analysis of Commercial Bank Credit, 1st Ed. Jakarta (ID): PT. Basic Noble Libraries.

32. Sutoyo, Siswanto. 2017. Commercial Bank Management. Jakarta (ID). PT Damar Mulia Pustaka.

33. Triwahyuniati, Nani. 2008. Implementation of Credit Analysis at PT. Bank Haga
Semarang Branch. (Thesis). Semarang (ID). Diponegoro University.

34. Walpole RE. 1993. Introduction to Statistics. Jakarta (ID). PT. Gramedia Mulia Pustaka.

35. Santoso, Moch Hadi. 2019. Determinants of Non-Performing Financing Factors in Islamic Commercial Banks (Case Study at BRI Syariah Bank). (Dissertation). Bogor (ID). IPB University.

How to cite this article: Suradi D, Siregar H, Sartono B. Non-performing loan determinants during COVID-19 pandemic (case study at Bank XYZ). International Journal of Research and Review. 2021; 8(12): 301-310. DOI: https://doi.org/10.52403/ijrr.20211237 